\title{
ANALISIS PERAN MENGAJAR GURU PADA PENINGKATAN MOTIVASI BELAJAR DAN KEPEDULIAN LINGKUNGAN SISWA TK MELATI CERIA SCHOOL SURABAYA
}

\author{
Asy'ari \\ Prodi Pendidikan Biologi, Fakutas Keguruan dan Ilmu Pendidikan, Universitas Muhammadiyah Surabaya \\ Surabaya, 60113, Indonesia \\ asyari@fkip.um-surabaya.ac.id
}

\begin{abstract}
Abstrak
Tujuan pemulisan ini untuk megetahui analisis peran guru pada peningkatan belajar peserta didik di TK Melati Ceria School Surabaya. Penelitian ini dilakukan dengan pendekatan kualitatif deskriptif, dengan jumlah 2 responden. Data diperoleh melalui observasi dan wawancara dengan pernyataan yang relevan. Kemudian mtode peneltian menggunakan jenis penelitian kualitatif deskriptif. Pengumpulan data melalui observasi, wawancara, dokumentasi. Data yang diperoleh dianalisis secara deskriptif melalui penjabaran dan diolah menjadi sebuah kalimat yang lebih runtut.Maka dari kesimpulan hasi penelitian menunjukkan bahwa belajar yang menyenangkan anak dapat dengan mudah menerima materi-materi yang diberikan tanpa adanya rasa malas pada diri anak karena ketertarikan mereka pada suasana belajar tersebut. Anak tidak akan memberontak untuk berangkat kesekolah. Dengan adanya pembelajaran diluar kelas atau diluar wilayah sekolah berupa karya wisata akan membuat anak tambah semangat dam termotivasi belajar dan mereka tertarik untuk mengetahui dan memperluas pengetahuannya tentang hal-hal lain yang ada disekitarnya. Tumbuhanya motivasi belajar karena peran guru yang profesiona memiliki kecakapan verbal dan non-verbal dengan menciptakan setrategi yang menyesuaikan kebutuhan anak dan menjadikan suasana pembelajaran yang menyenangkan.
\end{abstract}

Kata kunci: peran mengajar, guru, pembelajaran, siswa

\begin{abstract}
The purpose of this writing is to find out the analysis of the role of the teacher in improving the learning of students at Melati Ceria School Surabaya. This research was conducted with a descriptive qualitative approach, with 2 respondents. Data is obtained through observation and interviews with relevant statements. Then the research method uses descriptive qualitative research. Collecting data through observation, interviews, documentation. The data obtained were analyzed descriptively through elaboration and processed into a more coherent sentence. So from the conclusion of the research results showed that learning that pleases children can easily receive the material provided without a sense of laziness in children because of their interest in the learning atmosphere. that. Children will not rebel to go to school. With the learning outside the classroom or outside the school area in the form of tourism, the children will be encouraged and motivated to learn and they are interested in knowing and expanding their knowledge about other things around them. The growth of learning motivation because the role of the professional teacher has verbal and non-verbal skills by creating a strategy that adapts the child's needs and makes the learning atmosphere enjoyable
\end{abstract}

Keywords: teaching role, teacher, learning, students

\section{PENDAHULUAN}

Proses belajar mengajar
merupakan suatu proses yang
mengandung

guru dan peserta didik atas dasar hubungan timbal balik yang berlangsung pada suatu edukatif untuk mencapai tujuan tertentu. 
Interaksi inilah yang menjadi syarat utama dalam berlangsungnya proses pembelajaran. Seorang peserta didik dikatakan belajar apabila dapat mengetahui sesuatu yang dapat dipahami sebelumnya, kemudian dapat melakukan atau menggunakan sesuatu yang sebelumnya tidak dapat digunakannya termasuk sikap sehingga dengan proses pembelajaran dapat menemukan perubahan pada tingkah lakunya. Menurut Nasution (2016) sebaliknya seorang guru ketika mengajar TERUS berupaya membantu peserta didik untuk memperoleh perubahan tingkah laku yang dikehendaki, baik itu perubahan sikologis maupun peningkatan hasil belajar.

Dalam Undang-undang No. 20 Tahun 2003 tentang sitem pendidikan nasional disebutkan bahwa guru PAUD harus memiliki kompetensi pendidik atau guru pada lembaga pendidikan anak usia dini (PAUD) memiliki kualifikasi akademik sekurang kurangnya diploma empat (D-IV) atau Sarjana (S-1) dibidang Pendidikan Anak Usia Dini (S-1/ D-IV PG-PAUD), kependidikan lain, atau psikologi, dan memiliki sertifikasi profesi guru PAUD atau sekurang-kurangnya telah mendapat pelatihan pendidikan anak usia dini (Sayudi \& Ulfa, 2015). Banyak metode yang bisa dipilih oleh seorang guru dalam kegiatan belajar mengajar. Setiap guru yang akan mengajar diharapkan untuk memilih metode yang baik. Karena Baik dan tidaknya suatu metode yang akan digunakan dalam proses belajar mengajar terletak pada ketepatan memilih suatu metode yang sesuai dengan tuntutan proses belajar mengajar.

Rusijono (2010) menyatakan dalam penelitian keberhasilan peserta didik dalam proses pembelajaran yang disampaikan oleh seorang guru sangat tergantung pada keterampilan dalam mengajar yang memiliki banyak planning pembelajaran. Banyak peserta didik yang tidak mampu atau daya kemampuan peserta didik masih kurang dalam menangkap pelajaran pada proses pembelajaran yang disampaiakan oleh guru. Ada beberapa faktor yang mempengaruhi hasil belajar peserta didik, yang diantaranya yaitu faktor peserta didik itu sendiri, lingkungan sekitar, faktor guru dan tingkat kesukaran materi pelajaran serta fasilitas belajar yang kurang memadai. Namun bagi guru profesional harus mampu memperhatikan dirinya sehingga menjadi dasar untuk memberikan teladan kepada siswa. Ketika guru mengajar kurang menguasai bahan, kurang bisa menggunakan metode dengan fariatif, maka dalam proses pembelajaran berefek tidak menyenangkan, sehingga pelajaran membosankan dan daya tangkap konsentrasi peserta didik menjadi hilang.

Guru sebagai fasilitator dalam
proses pembelajaran bertugas
menciptakan situasi dan kondisi yang
memungkinkan terjadinya proses
belajar mengajar yang lebih efektif
dan efisien. Sebelum mengajar, guru

Guru sebagai fasilitator dalam proses pembelajaran bertugas menciptakan situasi dan kondisi yang memungkinkan terjadinya proses dan efisien. Sebelum mengajar, guru 
harus merencanakan kegiatan pengajaran secara sistematis, sehingga dapat terampil dalam proses belajar mengajar. Guru terampil sebaiknya melakukan berbagaiupaya untuk peningkatan prestasi belajar siswa, hal tersbut merupakan tanggung jawab semua guru dalam memperoleh kualitas sumber daya manusia. Pada undangundang RI Nomor 20 Tahun 2003 tentang Sistem Pendidikan Nasional disebutkan bahwa pendidik adalah tenaga kependidikan yang berkualifikasi sebagai guru, dosen, konselor, pamong belajar, widyaiswara, tutor, instruktur,fasilitator dan sebutan lain yang sesuai dengan kekhususannya serta berpartisipasi dalam menyelenggarakan pendidikan (Suryana, 2013).

Berdasarkan data yang diperoleh sejumlah 87,3 persen guru PAUD tidak memenuhi standar kompetensi. Standar kompetensi yang dimaksudkan yaitu dari standar kualifikasi akademik dan empat kompetensi yang harus dimiliki seorang guru PAUD yaitu kompetensi pedagogik, profesional, sosial dan kepribadian. Hal ini terjadi karena pendidik anak usia dini berasal dari latar belakang pendidikan yang berbeda,pendidik memiliki keterbatasan dalam mengakses program pengembangan diri, dan keterbatasan dukungan finansial Rendahnya standar kompetensi pendidik PAUD terlihat dari kualifikasi akademik pendidik. Salah satu kendala dari rendahnya kualitas guru tersebut karena ratarata guru PAUD bukan dari program studi atau jurusan PAUD. Berdasarkan data yang diperoleh sejumlah 14 persen pendidik PAUD berpendidikan sarjana namun selebihnya berlatar belakang pendidikan SMA, dan D2 bahkan ada pula yang hanya berdasarkaan pengalaman (Christianti, 2012).

$$
\text { Magta (2013) dalam }
$$

jurnalnya menjelaskan bahwa pendidikan anak usia dini tidak terlepas dari jasa guru. Guru sebagai tenaga profesional menurut undang undang dapat dicapai melalui program sertfikasi. Undang-undang nomor 20 tahun 2003 tentang Sistem Pendidikan Nasional, undang nomor 14 tahun 2005 tentang Guru dan Dosen, dan Peraturan Pemerintah Nomor 19 tahun 2005 tentang Standar Nasional Pendidikan mengamanatkan bahwa guru adalah pendidik profesional. Seorang guru atau pendidik profesional harus memiliki kualifikasi akademik minimum sarjana (S1) atau diploma empat (D4), menguasai kompetensi (pedagogik, profesional, sosial, dan kepribadian), memiliki sertifikat pendidik, sehat jasmani dan rohani, serta memiliki kemampuan untuk mewujudkan tujuan nasional.

Seorang guru PAUD tidak hanya dituntut pengajar yang bertugas menyampaikan materi pelajaran tertentu, tetapi juga harus berperan sebagai pendidik. Seperti yang dikatakan oleh Marienda dkk (2016) menyatakan bahwa sebagai seorang pendidik harus mampu 
memilih strategi pembelajaran yang tepat bagi peserta didikn. Karena itu dalam memilih strategi pembelajaran, pendidik harus memperhatikan keadaan atau kondisi peserta didik, bahan pelajaran serta sumber-sumber belajar yangada agar penggunaan strategi pembelajaran dapat diterapkan secara efektif dalam menunjang keberhasilan belajar peserta didiknya. Belajar dengan bermain yang menyenangkan adalah sebuah konsep tepat diterapkan pada anak anak usia dini. Karena kecenderungan mereka bermain sehingga dengan desain pembelajaran bermain yang dikonsep oleh guru menjadi dasar keberlangsungan anak usia dini belajara.

Pendidik PAUD sebagai seorang pembimbing harus merumuskan tujuan secara jelas, menetapkan waktuperjalanan, menetapkan jalan yang harus ditempuh, menggunakan petunjuk perjalanan, serta menilai kelancaran sesuai dengan kebutuhan dan kemampuan peserta didiknya.Semua itu didasari dengan kerjasama yang baik antara pendidik dan peserta didik. Kerjasama tersebut mutlak dilakukan meskipun pendidik menjadi pihak yang memberikan pengaruh utama dalam aspek pembelajaran. Sebagai pembimbing, pendidik memiliki berbagai hak dan tanggung jawab dalam setiap pembelajaran yang telah direncanakan sebelimnya. Kemudian pembelajaran harus berorientasi pada membentuk suasana pembelajaran yang menyenangkan sehingga dapat membangun kreatifitas dalam proses pertumbuhan dan perkembangannya (Wiyani, 2016).

Pembelajaran yang ditetapkan dalam berbagai proses pembelajaran harus bersifat spesifik dan operasional. Selain itu, tujuan pembelajran harus dinyatakan dalam bentuk yang khusus dan mengandung perilaku yang dapat diamati agar dapat diukur atau dinilai ketercapaiannya. Maka dari itu, dalam rangka pencapaian tujuan pendidikan nasional, salah satu komponen pembelajaran merupakan diri peserta didik sebagai sasaran pembelajaran, sehingga setiap peserta didik tumbuh motivasi untuk belajar. Hasil belajar akan menjadi optimal jika anak memiliki motivasi yang tepat. Jadi yang menjadi dasar itu semua tugas guru beserta konselor yang senantiasa mendesain bagaimana menciptakan kondisi atau suatu proses yang mendorong dan mengarahkan para peserta didik anak usia dini agar pada dirinya tumbuh motivasi yang maksimal (Hapsari, 2013).

Sebagai pendidik yang profesional, hendaknya perlu juga mengetahui standar kompetensi yang harus dimiliki.Sehingga tugas utama pendidik dalam membimbing, memotivasi dan memfasilitasi kegiatan pengasuhan serta pendidikan peserta didik PAUD dapat berjalan dengan optimal. Motivasi belajar tumbuh tidak lepas dari peran guru didalamnya yang mendesain pembelajaran sesuai 
dengan kebutuhan mereka. Sehingga Magta, (2013) dalam jurnalnya menyatakan anak usia dini dalam pertumbuhan dan pekembangannya sangat dipengaruhi langsung oleh lingkungan seperti yang disampaikan oleh John Lock (1632 - 1704) dalam teorinya anak yang dilahirkan dari rahim seorang ibu bagaikan kertas kosong "Tabulasara", yang mempengaruhi pertumbuhan dan perkembangannya kedepan adalah lingkungan sekitarnya.

\section{Metode Penelitian}

Jenis penelitian ini menggunakan deskriptif kualitataif dengan bermaksud menjelaskan situasi sosial secara holistic dan mendalam, menemukan pola menjelaskan konsep dan ingin mengetahui seberapa dalam peran guru pada peningkatan belajr peserta didik di TK Melati Ceria School Surabaya.Lokasi pada penelitian ini terletak dikota Surabaya, dengan mengambil responden Ibu Kepala Sekolah dan Guru TK Melati Ceria School Surabaya.

Alasan penelitian memilih sekolah tersebut karena kami ingin mengetahui bagaimana peran guru dalam perkembangan dan pengelolaansekolah di TK Melati Ceria School Surabaya. Kemudian waktu yang digunakan peneliti tanggal 29 Oktober 2016 yang menjadi objek penelitian adalah TKPAUD Melati Ceria School Surabaya. Jalan Sutorejo No. 91 Kecamatan Mulyorejo Kota Surabaya, Jawa Timur 60113.
Teknik yang digunakan untuk mengumpulkan data dalam penelitian ini adalah melakukan observasi, wawancara dan dokumentasi kepada orang-orang yang dipandang tahu tentang situasi sosial dalam objek penelitian.Kemudian peneliti mereview semua data tersebut, memberikan makna dan mengolahnya kedalam kategorikategori atau tema-tema yang melintasi semua sumber data. Adapun yang dijadikan subjek penelitan pada tesis ini diantaranya yaitu: Kepala Sekolah dan Para Guru di TK-PAUD Melati Ceria School.

Pengolahan data dalam penelitian ini untuk memperoleh data ringkasan dengan cara-cara tertentu.Kemudian pengolahan data ini bertujuan mengubah data mentah dari hasil wawancara menjadi data yang lebih halus sehingga memberikan arah untuk pengkajian lebih lanjut. Proses analisis data dimulai dengan mengolah dan mempersiapkan data, yaitu melibatkan transkripsi wawancara, men-scenning materi, mengetik data lapangan, atau memilah-milah dan menyusun data tersebut ke dalam jenis-jenis yang berbeda bergantung pada sumber informasi.

Memanfaatkan alokasi waktu yang relatif lama dilokasi penelitian dapat memahami lebih dalam fenomina yang diteliti dan dapat menyampaikan secara detail mengenai lokasi dan orang-orang yang turut membangun kredibilitas hasil naratif penelitian. semakin banyak pengalaman yang dilakukan 
maka semakin akurat atau valid data penelitian. Kevalidan penelitian kualitatif adalah tidak sama dengan penelitain kuantitatif. Penelitian kualitatif tidak dibatasi waktu, maka semakin lama penelitian semakin akurat data yang diperoleh.

\section{Hasil dan Pembahasan}

\section{Hasil Penelitian}

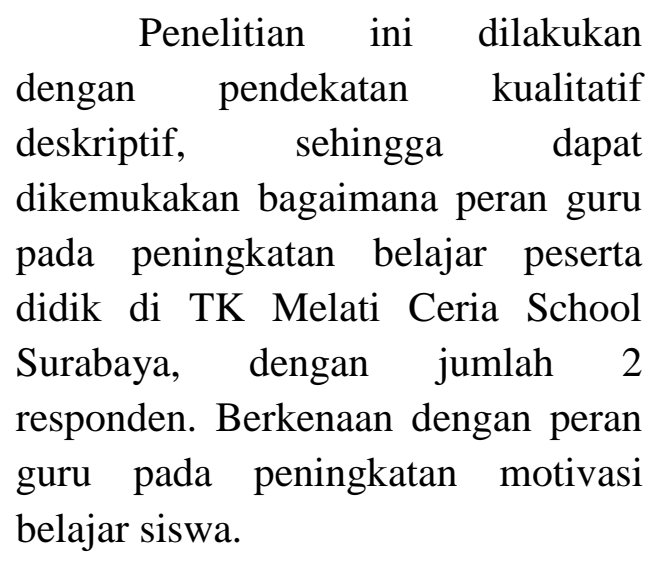

Cara guru menciptakan suasana belajar yang menyenangkan peserta didik Melati Ceria School

Sesuai dengan hasil observasi yang peneliti lakukan di lapangan, tepatnya di TK Melati Ceria School, terkait menciptakan suasana belajar yang menyenangkan di TK Melati Ceria School sudah berhasil karena ada beberapa fasilitas yang turut membantu untuk menciptakan suasana belajar yang menyenangkan bagi peserta didik TK Melati Ceria School. Misalnya, seperti ada bermacam sentra, disediakannya kostum untuk anak bermain peran, karya wisata (pembelajaran diluar lingkungan sekolah). Sesuai dengan wawancara dengan Ibu Kepala Sekolah TK Melati Ceria School yang berinisal "LH" menyatakan bahwa:

"Guru meciptakan
suasana belajar yang
menyenangkan dengan
cara, setiap pagi anak
melakukan gerakan atau
olahraga ringan sesuai
tema yang telah diberikan
oleh guru setiap harinya.
Untuk mengenalkan anak
padar lingkungan disekitarnya dengan cara yang menyenangkan. Misalnya dengan tema binatang, contoh binatang yang digunakan adalah burung kutilang, jadi anak diberikan gerakan bagaimana layaknya burung kutilang, dan diberikan lagu yang sesuai dengan tema. Untuk mengenalkan bagaimana bentuk kutilang menggunakan sentra yang lain, agar anak tidak merasa bosan berada di satu tempat saja. Di TK Melati Ceria School menggunakan sentra misal motorik halus, motorik kasar, bahasa dan lain sebagainya".

Dengan metode diatas ternyata anak lebih tertarik dan termotivasi untuk belajar. Mereka tidak merasa bosan dengan adanya lagu dan gerakan-gerakan yang dilakukan setiap hari secara bergantian. Lebih tepatnya, dengan 
adanya sentra anak tidak bosan untuk belajar. Artinya suasana pembelajaran lebih menyenangkan yang diberikan kepada peserta didik anak usia dini yang mimang dunia anak adalam bermain dan bersenangsenang. Seperti halnya yang disampaikan oleh guru TK TK Melati Ceria School yang berinisial "SW" menjelaskan yaitu:

"anak ketika pembelajaran

menyesuaikan dengan kebutuhan mereka, namun kami sebagai guru selalu banyak cara untuk memberikan alternatif, dan yang dilakukan dengan menyanyi misalnya balunku ada lima, terima kasih guru, tepuk tangan TK dan lain-lain. Misalnya tepuk tangan dan ada yang salah bertepuk tangan tidak sesuai maka diberikan sanksi dengan bernyanyi. Kemudian anak-anak juga belajar membersihkan halaman sekolah dan kelas untuk membiasakan anak cinta kebersihan".

Dari hasil wawancara ini dapat memberi gambaran bahwa anak usia dia cenderung bermain (psikomotorik), maka dengan hal itu peran guru menentukan proses pertumbuhan dan perkembangannya. Dalam sisi yang lain peran guru menjadi $\begin{array}{lr}\text { sangat penting } & \text { dalam } \\ \text { menciptakan } & \text { suasana } \\ \text { pembelajaran } & \text { yang }\end{array}$ menyenangkan, sehingga untuk menimbulkan hal itu suasana pembelajaran bergantung bagaimana peran guru menciptakan beberapa alternatif pembelajaran sehingga motivasi belajar anak usia dini benar-benar tumbuh.

Cara guru meningkatkan motivasi belajar peserta didik TK Melati Ceria School

Menurut observasi yang kami lakukan, pada tanggal 28 Agustus 2016, guru meningkatkan belajar peserta didik di TK Melati Ceria School dengan cara, mereka melakukannya menggunakan sentra dan melakukan pembelajarannya secara berurutan. Misalnya bertemakan hewan.Tema merupakan alat atau wadah untuk mengedepankan berbagai konsep kepada peserta didik secara utuh Pertama yang dilakukan adalah dengan mengenalkan gambar hewan, contoh burung kutilang dan pengenalan selanjutnya dengan cara anak itu diajak untuk senam misalnya dengan menggunakan lagu burung kutilang, diajak untuk menirukan burung kutilang itu terbang, bagaimana bunyi burung tersebut,dan lain-lain. Dan langkah selanjutnya agar anak bisa lebih nyata lagi mengetahui burung kutilang, diajaklah anak untuk pergi karya wisata (pembelajaran diluar sekolah).Kerena metode-metode 
tersebut merupakan segala sumber yang secara sengaja dirancang atau didesain untuk kepentingan pencapaian tujuan pembelajaran. Seperti yang disampaikan wawancara dengan Ibu Kepala Sekolah TK Melati Ceria School yang berinisal "LH" menjelaskan:

"Untuk meningkatkan motivasi belajar peserta didik TK Melati Ceria School, ada beberapa cara yang dilakukan. Meliputi, kegiatan tahunan dan karya wisata yang dilakukan rutin setiap tahunnya. Kegiatan tahunan yang sering dilakukan adalah bakti social yang dilakukan setiap 17 ramadhan mengajari anak bagaimana peduli dengan lingkunga sekitarnya, hidup tolong menolong, mengenalkan bahwa kita hidup membutuhkan orang lain. Kegiatan lainnya adalah karya wisata yang kami lakukan setiap semester 1 dan 2 yaitu outbond yang sering kita lakukan dibeberapa tempat yaitu, Kampung Kid, Sengkaling, Selekta, Songgoriti itu yang kegiatan ekstern, yang kegiatan internnya belajar diperpustakaan di putarkan film terjadinya kupu-kupu, dengan lagunya kan anak-anak suka itu, selama ini saya amati anak-anak lebih cepat hapal dan tidak mudah lupa. roling setelah itu kebun bibit, kebun binatang, sidoarjo (tidak disebutkan tempatnya), dan kemudian rencananya nanti akan ke alas prambon bulan desember ini. Disinikan tidak ada kebun tidak ada binatang jadi hanya dikenalkan gambarnya saja, dengan menggunakan sentra, anak tidak akan kaku lagi saat pengenalan binatang dan tumbuhan secara nyata kata ibu LH selaku kepala sekolah TK Melati Ceria School"

Berdasarkan hasil wawancara diatas, bermain sambil belajar merupakan dunia mereka, dunia Anak Usia Dini (AUD), maka dengan cara seperti ini anak-anak lebih dapat menerima apapun yang disampaikan. Karena tidak monoton seperti yang diajarkan pada jenjang pedidikan diatasnya yaitu pada sekolah dasar. Adapun seperti yang disampaikan oleh ibu guru TK TK Melati Ceria School yang berinisial "SW" yaitu: Dengan lagu, video, dan kegiatan-kegiatan diluar kelas anak lebih cepat menangkap. Karena anak pada tingkan TK ini tidak seperti anak SD, SMP dan seterusnya.Anakanak setingkat TK 
memerlukan kasih sayang lebih dan pendekatan kasih sayang agar memberikan kesenengan kepada mereka.lagipula ketika proses pembelajaran belangsung selalu diajarin saling bekkerjasama anatar sesama temannya. Dan diajarin pula bermain dilingkungan alam seperti outbond baik dilingkungan taman di surabaya dan juga ketika semester 1 dan 2 seperti Kampung

Kid,

Sengkaling, Selekta, Songgoriti dan lain-lain. Hal seperti itu tujuannya untuk memberi sensasi baru atau nuasa baru kepada mereka kemudian memberikan

pemandangan lansung terhadap lingkungan alam betapa pentingnya menjaga dan melestarikannya.

Dari wawancara ini dapat menguatkan bahwasanya peran guru pada peningkatan belajar peserta didik itu sangant penting. Dengan adanya guru yang kreatif dan profesional,maka hasil belajar peserta didik juga akan baik. Guru memberikan kebebasan pada peserta didik untuk berkreasi bukan untuk membatasi apapun yang dikerjakan oleh peserta didik tersebut dan peserts didik bebas melakukan apa saja sambil ada bimbingan dari seorang guru yang mendampingi.

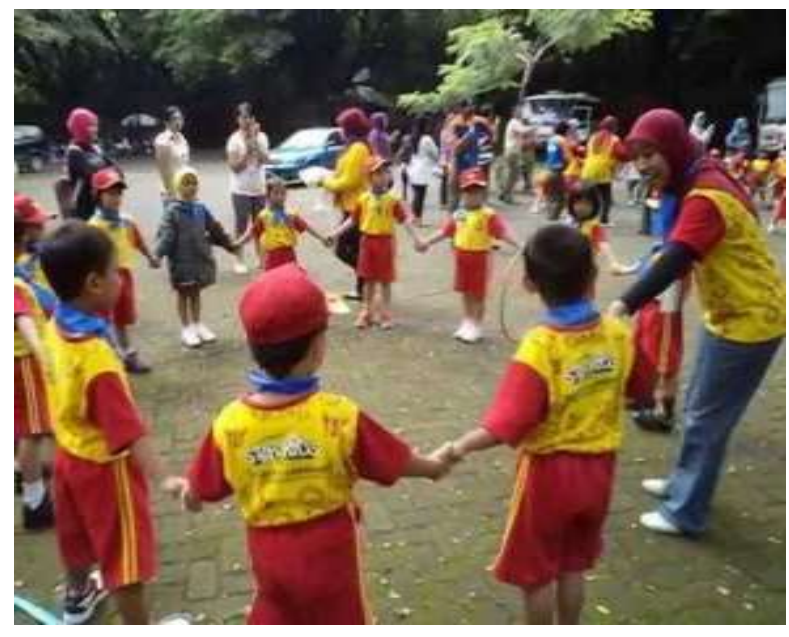

Gambar 1. Kegiatan Pembelajaran

TK melati ceria school Surabaya

\section{Pembahasan}

Hasil penelitian yang
dilakukan oleh peneliti untuk motivasi belajar peserta didik tidak lepas dari peran guru sebagai fasilitator. Karena sesungguhnya semangat belajar peserta didik dapat tumbuh tidak lepas dari pengaruh peran guru dengan melaui pendekatan dan setrategi mengajar sehingga pembelajaran memberikan dampak menyenangkan dikelas. Scarai psikologis, peserta didik sebagai manusia biasa akan cenderung tidak memperhatikan guru dalam proses pembelajaran jika seorang guru tidak bersikap baik dan menyenangkan bagi peserta didik. Apalagi jika cara mengajarnya monoton tidak dapat berbaur dangan baik maka mereka akan cenderung bosan. Kemudian peran guru pada peningkatan belajar peserta didik memiliki pengaruh positif dalam menunjang kesiapan belajar peserta 
didik, sehingga demikian motif peran guru akan memberikan dampak positif terhadap kemajuan belajar peserta didik, yang diwujudkan melalui kesungguhan dalam mempersiapkan kegiatan pembelajaran yang menyenangkan (Darkasyi, 2014).

Disisi lain dari hasil penelitian diperoleh timbulnya perilaku positif dari peranan gaya mengajar guru pada motivasi dan kepeduliaan lingkungan peserta didik menjadi salah satu keberhasilan guru mendi fasilatator bagi mereka. Ini berarti semakin banyak variasi atau gaya mengajar guru kepada peserta didik maka motivasi belajar i belajar peserta didik semakin meningkat. Dalam pembelajaran dikelas, variasi mengajar sorang guru merupakan salah satu faktor sangat penting dalam mensukseskan proses pembelajaran peserta didik.

Penguatan yang baik dan tepat dari seorang guru menambah rasa gairah, rasa aman, semangat, dan perasaan senang peserta didik dalam mempelajari berbagai materi yang diberikan oleh guru. Guru profesional tentunya memiliki kompotensi 4 kategori yang diantranya adalah pedagogi, kepribadian, sosial dan profesional. Karena ko,ptensi itu guru mampu memberikan nuansa pembelajaran yang lebih produktif dan menyenangkan (Hapsari, 2013).

$\begin{array}{lll}\text { Menurut } & \begin{array}{l}\text { Suryana (2013) } \\ \text { peningkatkan motivasi belajar } \\ \text { peserta didik dalam segala hal. }\end{array}\end{array}$

Kemudian peserta didik termotivasi untuk belajar tidak lepas bagaimana seorag guru mengkondisikan, karena seorang memiliki karakteristik yang berbeda antara yang satu dengan lain terutama setiap guru kelas. Sebagai pendidik professional, pendidik PAUD idealnya berperan dalam mendidik, mengajar, membimbing melatih, dan mengefaluasi peserta didiknya (UU RI, 2005).Sehingga ada beberapa karakteristik guru yang efektif dengan diantaranya yaitu antusiasme mengajar cukup baik, berwawasan luas, proaktif, komunikator, sabar dan bisa beradaptasi terhadap perubahan lingkungan, dan akhirnya dapat memunculkan lingkungan belajar yang lebih kondusif dan menyenangkan sehingga peran guru dalam proses belajar sangat dibutuhkan. Karena guru menjadi tenaga fungsional yang memiliki kecerdasan untuk belajar sambil mengajar dan mengajar sambil belajar.

Dalam hal ini karakteristik guru PAUD harus memiliki landasan keilmuan yang kuat tentang perkembangan anak bagaimana belajar secara baik dan efektif. Karakteristik ini hanya dapat diperoleh melalui latihan, membaca, dan mengamati berbagai persoalan yang sesuai dengan kontek dunia anak-anak. Pendidik yang profesional dapat mengetahui perkembangan anak dari membaca, kemudian mengamati perkembangan ank-anak secara nyata. Sehingga dengan mengobservasi anak dengan 
baik pendidik mengetahui kebutuhan anak, dan setiap anak memiliki kebutuhan yang berbeda-beda. Hasil dari observasi tersebut kemudian digunakan untuk membuat program yang relevan dengan kurikulum anak usia didik. Kemudian sebagai pendidik selalu berlatih untuk mengembangkan program yang sesuai dengan kebutuhan anak dan sesuai dengan kurikulum yang menjadi kebijakan sekolah (Christianti, 2012).

Lingkungan alam menjadi salah satu tempat strategis untuk pembelajaran anak-anak tingkat TK. Kecenderungan anak lebih kepada bermain, maka dengan berbagai permainan yang didalamnya ada nilai edukasi, sehingga anak-anak bengikuti dengan gembira. Dunia anak tidak sama dengan orang dewasa. Maka sebagai guru TK harus masuk kedalam dunia anak dengan rasa kasik sayang sehingga menjadi salah satu upaya pendekan yang dilakukan untuk mempngaruhi motivasi belajar mereka. Karena motivasi belajara terdiri 2 kategori yakni intrinsik dan ekstrinsik. Intrinsik adalah faktor yang dipengaruhi dari dalam dirinya, sedangkan ekstrinsik adalah faktor yang dipengaruhi dari lauar. Dalam konteks ini adalah upaya guru untuk terus berupaya menjadikan suasana pembelajaran lebih efektif dan menyenangkan. Seperti yang disampaikan Rusijono (2010) Pengembangan kemampuan dasar merupakan kegiatan yang dipersiapkan guru untuk meningkatkan kemampuan dan kreativitas anak sesuai dengan tahap perkembangannya.

Penanaman kepedulian lingkungan sejak dini menjadi arget dalam proses pembelajaran anakanak TK. Ketika anak-anak dibiasakan setiap hari untuk hidup rapi, membuang sampah pada tempatnya, membersihkan halaman sekolah dan sambil didampingi oleh guru menjadi salah satu penanaman kepedulian lingkungan sejak diri. Anak-anak tidak akan dapat memperdulikan lingkungan dengan baik kalau guru tidak berperan didalamnya untuk membiasaan anakanak untuk peduli Sari dkk (2016) dalam artikelnya menjelaskan Bahwa Usia sekolah anak usia dini merupakan usia penting dalam pertumbuhan dan perkembangan fisik anak. Periode ini juga disebut sebagai periode kritis karena pada masa ini anak mulai mengembangkan kebiasaan yang biasanya cenderung menetap sampai dewasa. Maka disitulah peran guru menjadi penting untuk terus memandu mendampingi mereka sebagai bentuk untuk membiasakan mereka sejak dini.

Hidayatulloh (2014). Dalam penyelenggaraan TK, sebaiknya lingkungan diarahkan kepada bentuk yang berkualitas. Sebab lingkungan merupakan bagian dari sarana dan prasarana yang signifikan. Dalam Peraturan Menteri Pendidikan Nasional Republik Indonesia Nomor 58 Tahun 2009 tentang Standar Pendidikan Anak Usia Dini telah 
dituangkan bahwa sarana prasarana di PAUD hendaknya memenuhi prinsip-prinsip berikut: 1) aman, nyaman, terang, dan memenuhi kriteria kesehatan bagi anak; 2) sesuai dengan tingkat perkembangan anak; dan 3) memanfaatkan potensi dan sumber daya yang ada di lingkungan sekitar, termasuk barang limbah atau bekas layak pakai. Karena dengan seperti itu menjadi jalan alternatif yang memberikam anak senang dan termotivasi untuk mengikuti proses pembelajara dilur kelas maupun di luar kelas.

Disisi yang lain bahwa peran guru berdampak pada motivasi belajar dan kepedulian lingkungan peserta didik. Kalau ditinjau dalam Hadits Rasulullah SAW yang menjelaskan shohih bukhari no. 1296 berbunyi:"Telah menceritakan kepada kami Adam telah menceritakan kepada kami Ibnu Abu Dza'bi dari Az Zuhriy dari Abu Salamah bin 'Abdurrahman dari Abu Hurairah radliallahu 'anhu berkata; Nabi Shallallahu'alaihiwasallam bersabda:

"Setiap anak dilahirkan dalam keadaan fithrah. Kemudian kedua orang tuanyalah yang akan menjadikan anak itu menjadi Yahudi, Nashrani atau Majusi sebagaimana binatang ternak yang melahirkan binatang ternak dengan sempurna”. Hal ini menjadi landasan bahwa anak usia dini masih fitrah (suci) yang mempengaruhi perkembangan dan pertumbuhannya adalah lingkungannya sperti lingkngan sekolah, keluarga dan masyarakat. Konteks disini adalah taman kanak-kanak maka peran guru yang menjadi penting untuk terus dimasifkan.

\section{SIMPULAN}

Dari penelitian yang di dapatkan terkait analisis peran mengajar guru pada peningkatan motivasi belajar dan kepedulian lingkungan peserta didik TK melati ceria school Surabaya dapat disimpulkan sebagai berikut:

1. Cara guru menciptakan suasana belajar yang menyenangkan peserta didik Melati Ceria School dapat disimpulkan yaitu dengan suasana belajar yang menyenangkan anak dapat dengan mudah menerima materi-materi yang diberikan tanpa adanya rasa malas pada diri anak karena ketertarikan mereka pada suasana belajar tersebut. Anak tidak akan memberontak untuk berangkat kesekolah. Dengan adanya pembelajaran diluar kelas atau diluar wilayah sekolah berupa karya wisata akan membuat anak tambah semangat, tertarik untuk mengetahui dan memperluas pengetahuan anak tentang hal-hal lain yang ada disekitarnya.

2. Cara guru meningkatkan motivasi belajar dan kepedulian peserta didik TK Melati Ceria School dapat disimpulkan bahwa tema merupakan atau wadah untuk mengedepankan berbagai konsep kepada peserta didik secara utuh yang pertama dilakukan adalah dengan mengenalkan gambar hewan, seperti burung kutilang 
dan pengenalan selanjutnya dengan cara anak itu diajak untuk senam misalnya dengan menggunakan lagu burung kutilang, diajak untuk menirukan burung kutilang itu terbang, bagaimana bunyi burung tersebut,dan lain-lain. Dan langkah selanjutnya agar anak bisa lebih nyata lagi mengetahui burung kutilang dan lingkungan, diajaklah anak untuk pergi karya wisata (pembelajaran diluar sekolah).

\section{DAFTAR PUSTAKA}

Christianti, M. (2012)

Profesionalisme Pendidik Anak Usia Dini. Jurnal Pendidikan Anak, Volume 1, Edisi 1, Juni

Darkasyi, M. (2014). Peningkatan Kemampuan Komunikasi Matematis dan Motivasi Siswadengan Pembelajaran Pendekatan Quantum Learning pada Siswa SMP Negeri 5 Lhokseumawe. Jurnal Didaktik Matematika. Vol. 1, No. 1, April, ISSN : 2355-4185

Darwin, S. (2007). Perencanaan Sistem Pengajaran Pendidikan Agama Islam. Jakarta

Hapsari, R. P. (2013). Studi Tentang Pelaksanaan Pemberian Reward Dalam Meningkatkan Motivasi Belajar Kelompok-A Di Tk Islam Al-Azhar 35 Surabaya. Jurnal BK Unesa. Volume 04 Nomor 01 Tahun. 274-284
Hidayatulloh, M. A. (2014). Lingkungan Menyenangkan dalam Pendidikan Anak Usia Dini: Pemikiran Montessori. Nadwa Jurnal Pendidikan Islam, Vol. 8, Nomor 1, April Magta, M. 2013. Konsep Pendidikan Ki Hajar Dewantara Pada Anak Usia Dini. Jurnal Pendidikan Usia Dini Volume 7 Edisi 2, November

Marienda, W dkk. (2016). Kompetensi Dan Profesionalisme Guru Pendidikan Anak Usia Dini. Prosiding Ks: Riset \& PKM. Volume 2, Nomor 2. HAL: 147 - 300, ISSN: 2442-4480

Nasution, M,I,P. 2016. Strategi pembelajaran efektif berbasis mobile learning pada sekolah dasar. Jurnal Iqra' Volume 10 No.01. Mei

Rusijono. (2010). Kurikulum dan Teknologi Pendidikan, Fakultas Ilmu Pendidikan Universitas Negeri Surabaya Kampus Lidah Wetan. Jurnal Teknologi Pendidikan, Vol.10 No. 1, April (38-45)

Rusijono. 2010. Kompetensi Guru Taman Kanak-Kana. Jurnal Teknologi Pendidikan, Vol.10 No. 1, April, 38-45

Sari, E. K dkk (2016). Pengaruh Pendidikan Kesehatan Gosok Gigi Dengan Metode Permainan Simulasi Ular Tangga Terhadap Perubahan Pengetahuan, Sikap, Dan 
Aplikasi Tindakan Gosok Gigi Anak Usia Sekolah Di Sd Wilayah Paron Ngawi.

Program Studi S1 Ilmu Keperawatan Fakultas

Keperawatan Universitas Airlangga Kampus C Mulyorejo Surabaya

Sayudi \& Ulfa, Maulidya (2015)

.Konsep Dasar PAUD.

Bandung
Suryana, D. 2013. Profesionalisme Guru Pendidikan Anak Usia Dini Berbasis Peraturan Menteri No. 58 tahun 2009. PEDAGOGI Jurnal Ilmiah Ilmu Pendidikan. Volume XIII No. 2 November

Undang-undang RI Nomor 14 Tahun 2005. Tentang Guru dan Dosen pada pasal 1

Wiyani N. A (2016) .Konsep Dasar PAUD. Jogjakarta. 